THE HANDBOOK OF

COMPARATIVE CRIMINAL LAW 



\title{
THE HANDBOOK OF
}

COMPARATIVE CRIMINAL LAW

\author{
Edited by KEVIN JON HELLER \\ AND MARKUS D. DUBBER
}


Stanford University Press

Stanford, California

C 2011 by the Board of Trustees of the Leland Stanford Junior University. All rights reserved.

No part of this book may be reproduced or transmitted in any form or by any means, electronic or mechanical, including photocopying and recording, or in any information storage or retrieval system without the prior written permission of Stanford University Press.

Printed in the United States of America on acid-free, archival-quality paper

Library of Congress Cataloging-in-Publication Data

The handbook of comparative criminal law / edited by Kevin Jon Heller and Markus D. Dubber.

p. $\mathrm{cm}$.

Includes bibliographical references and index.

ISBN 978-0-8047-5758-4 (cloth : alk. paper)

1. Criminal law. 2. Comparative law. 1. Heller, Kevin Jon. II. Dubber, Markus Dirk.

K5015.4.H36 2011

345-dc22 2010020243

Typeset by Westchester Book Group in 10/13.5 Minion. 